\title{
EVALUATION OF THE RECOVERY TIME OF SEA BASS (DICENTRARCHUS LABRAX LINNAEUS, 1758) JUVENILES FROM TRANSPORT AND HANDLING STRESS: USING AMMONIA NITROGEN EXCRETION RATES AS A STRESS INDICATOR
}

\author{
Betül Kayali \\ Directorate of Special Provincial Administration - Il Ozel Idare Mudurlugu, Canakkale-17000, Turkey. \\ Murat Yigit \\ Canakkale Onsekiz Mart University, Faculty of Fisheries, Department of Aquaculture, Canakkale-17000, Turkey., \\ muratyigit2@hotmail.com \\ Musa Bulut \\ Canakkale Onsekiz Mart University, Faculty of Fisheries, Department of Aquaculture, Canakkale-17000, Turkey.
}

Follow this and additional works at: https://jmstt.ntou.edu.tw/journal

Part of the Engineering Commons

\footnotetext{
Recommended Citation

Kayali, Betül; Yigit, Murat; and Bulut, Musa (2011) "EVALUATION OF THE RECOVERY TIME OF SEA BASS

(DICENTRARCHUS LABRAX LINNAEUS, 1758) JUVENILES FROM TRANSPORT AND HANDLING STRESS: USING

AMMONIA NITROGEN EXCRETION RATES AS A STRESS INDICATOR," Journal of Marine Science and Technology. Vol.

19: Iss. 6, Article 13.

DOI: $10.51400 / 2709-6998.2211$

Available at: https://jmstt.ntou.edu.tw/journal/vol19/iss6/13

This Research Article is brought to you for free and open access by Journal of Marine Science and Technology. It has been accepted for inclusion in Journal of Marine Science and Technology by an authorized editor of Journal of Marine Science and Technology.
} 
EVALUATION OF THE RECOVERY TIME OF SEA BASS (DICENTRARCHUS LABRAX LINNAEUS, 1758) JUVENILES FROM TRANSPORT AND HANDLING STRESS: USING AMMONIA NITROGEN EXCRETION RATES AS A STRESS INDICATOR

\section{Acknowledgements}

The authors would like to thank Prof. Dr. Şükran CIRIK, Dean of the Faculty of Fisheries at Canakkale Onsekiz Mart University (COMU), for his valuable support throughout the study, which has been performed in partial fulfillment of requirements for the degree of Master of Science of the first author. Ida Gida AS (Marine Fish Farm), Canakkale-Turkey is gratefully acknowledged for their support of the experimental fish. 


\title{
EVALUATION OF THE RECOVERY TIME OF SEA BASS (DICENTRARCHUS LABRAX LINNAEUS, 1758) JUVENILES FROM TRANSPORT AND HANDLING STRESS: USING AMMONIA NITROGEN EXCRETION RATES AS A STRESS INDICATOR
}

\author{
Betül Kayali*, Murat Yigit**, and Musa Bulut**
}

Key words: Sea bass, stress, recovery, ammonia, nitrogen, excretion, transport.

\begin{abstract}
A time-course study was conducted in order to evaluate the recovery time of juvenile Sea bass (Dicentrarchus labrax) from transport and handling stress. Among metabolite indices, ammonia nitrogen excretion rates were used as stress indicator. The measurements were carried out in water ambience of $13 \pm$ $1{ }^{\circ} \mathrm{C}$ under natural light conditions (16L/8D photoperiod). Juveniles were transported for about 2 hours in a fish transport tank with oxygen supply. Handling stress was due to netting at the outlet site during stocking fish into the transport tank and netting at the experimental facility while transferring fish from transport tank into experimental tanks. At the end of transportation, ammonia nitrogen excretion rates of sea bass juveniles in the transport tank became about 4 times higher than that in sea water at the outlet facility. Ammonia nitrogen concentrations in fish exposed to transport and handling stress peaked 10 hours after stocking in to the tanks, and then declined to initial values $24 \mathrm{~h}$ after stocking. In fish under normal condition and without stress, the postprandial trend of ammonia nitrogen excretion was similar, however, a peak was reached 6 hours after feeding, and then decreased to initial values $24 \mathrm{~h}$ after feeding. Based on the duration for recovery of ammonia nitrogen excretion in fish, it is suggested that sea bass juveniles may completely recover from stress caused by transportation and handling, and return to normal feeding
\end{abstract}

Paper submitted 11/23/09; revised 05/25/10, 07/16/10; accepted 12/14/10. Author for correspondence: Murat Yigit (e-mail: muratyigit2@hotmail.com). *Directorate of Special Provincial Administration - Il Ozel Idare Mudurlugu, Canakkale-17000, Turkey.

**Canakkale Onsekiz Mart University, Faculty of Fisheries, Department of Aquaculture, Canakkale-17000, Turkey. conditions in 24 hours after a 2 hour truck transport.

\section{INTRODUCTION}

Fish in intensive aquaculture activities are usually subject to physical disturbance, in terms of transportation, netting, sorting, sizing or other means of handling procedures. Producing healthy market size fish in a short time frame is the main goal in aquaculture, where feeds and feeding frequency play an important role in this aim. It is known in practice that fish do not accept feed well when they are under stress caused by means of reasons. Hence, evaluation of stress or the recovery time from stress is important for estimating the physiological status of fish and so decide for the best timing to start feeding.

Many studies have been concentrated on stress indicators such as plasma cortisol, glucose, hematocrit, and ion balance $[15,22,31]$, however, the use of un-ionized ammonia nitrogen $\left(\mathrm{NH}_{3}-\mathrm{N}\right)$ concentration in the water ambience as a stress indicator seems to be practical and feasible as ammonia excretion rates tend to increase together with the metabolic rate in fish exposed to acute stress conditions. Russo and Thurston [20] and and Timmons et al. [25] reported that exposure of fish to increased ammonia concentration decrease growth rates, fecundity, disease resistance, and swimming performance, and it increases metabolic rate. Portz et al. [16] reported that temperature, dissolved oxygen, ammonia, nitrite, nitrate, salinity, $\mathrm{pH}$, carbon dioxide, alkalinity and hardness are the most common water quality parameters affecting physiological stress, and any adverse conditions in these water parameters may contribute to fish health and stress levels. Metabolite indices such as ammonia nitrogen excretion or pulsatile urea excretion may increase in appearent stress conditions, such as crowding, confinement, or air exposure [2, 28]. Furthermore, high levels of ammonia, an indicator of toxicity, may also effect fish behavior as a response to acute stress conditions [30]. 
Table 1. Experimental tanks and stocking densities (mean \pm SD*).

\begin{tabular}{lccc}
\hline \multirow{2}{*}{ Parameters } & \multirow{2}{*}{ Transport tank } & \multicolumn{2}{c}{ Experimental tanks } \\
\cline { 3 - 4 } & & $\mathrm{RT}$ & $\mathrm{CT}$ \\
\hline Tank volume (L) & 200 & 500 & 500 \\
Fish in tank (inds.) & 1200 & 388 & 388 \\
Fish weight $(\mathrm{g}) *$ & $1.83 \pm 1.0$ & $1.83 \pm 1.0$ & $1.83 \pm 1.0$ \\
Stocking density $\left(\mathrm{kg} / \mathrm{m}^{3}\right)$ & 10.98 & 1.42 & 1.42 \\
\hline
\end{tabular}

RT, recovery tank

CT, control tank

The aim of the present study was to investigate recovery time of fish from transport and handling stress using ammonia nitrogen $\left(\mathrm{NH}_{3}-\mathrm{N}\right)$ excretion as a fast and practical method to determine the time when fish can start effectively feeding in a commercial sea bass farm after transportation.

\section{MATERIALS AND METHODS}

Totally 1200 hatchery reared sea bass juveniles, obtained from a commercial sea bass farm (Ida Gida AS., CanakkaleTurkey) were fasted for 24 hours prior to transport. Fish were transferred to the transport tank by a hand net and hauled in an oxygenated transport tank containing 2001 sea water (31.4\%o salinity). Experimental fish were transported for 2 hours from the commercial farm to the marine aquaculture research unit of the Faculty of Fisheries at Canakkale Onsekiz Mart University in Canakkale, Turkey in June 2008. As seawater salinity at the research station was $26.7 \%$, fish were gradually acclimatized to the new water condition inorder to minimize salinity stress. Acclimatization was performed by gradually adding seawater from the research facility into the transport tank. Thereafter, 776 fish were randomly selected and distributed by a hand net into two cylindrical-conic experimental tanks containing 5001 seawater of $26.7 \%$ o salinity (388 fish in each tank, average fish weight $1.83 \pm 1 \mathrm{~g}$ ). One tank was assigned as the experimental recovery tank (RT) and the other tank served as the control tank (CT). Tank volumes and fish stocking densities are given in Table 1.

Experimental water conditions such as temperature, salinity and oxygen levels are given in Table 2 . Water temperature at the the commercial fish farm (outlet site) was $13^{\circ} \mathrm{C}$ and increased $2.5^{\circ} \mathrm{C}$ during the course of 2-h tranportation and reached $15.5^{\circ} \mathrm{C}$ at the end of the transport. As the water temperature at the experimental site was $13.7^{\circ} \mathrm{C}$, fish were transferred to the new environment by gradually lowering the water temperature to $14 \pm 1^{\circ} \mathrm{C}$.

The stress recovery experiment in the RT started immediatelly after transport, while adequate time was given for fish in the CT to fully recover from stress. The CT fish recovery time was determined by RT stress recovery experiment. RT water samples were taken immediately after transfer at $0,2,4,6,10,16$ and 24 hour intervals. Unionized ammonia
Table 2. Experimental water conditions (mean $\pm \mathrm{SD}^{*}$ ).

\begin{tabular}{lcccc}
\hline Parameter & OS $^{1}$ & ESS $^{2}$ & TT $^{3}$ & ET (RT\&CT) \\
\hline NH3-N mg/L* & $0.22 \pm 0.05$ & $0.25 \pm 0.12$ & $0.88 \pm 0.17$ & $0.31 \pm 0.10$ \\
Salinity (\%o) & 31.4 & 27.1 & 31.4 & 26.7 \\
Temperature $\left({ }^{\circ} \mathrm{C}\right)$ & 13.0 & 14.0 & 15.5 & 13.7 \\
Oxygen (mg/L) & 8.4 & 8.3 & 10.2 & 8.2 \\
pH & 7.5 & 7.6 & 8.1 & 7.6 \\
${ }^{1} \mathrm{OS}=$ outlet site, the departure facility prior to transportation \\
${ }^{2} \mathrm{ESS}=$ experimental sea site \\
${ }^{3} \mathrm{TT}=$ transport tank \\
${ }^{4} \mathrm{ET}=$ experimental tanks, values for both recovery tank (RT) and control tank \\
$(\mathrm{CT})$
\end{tabular}

concentrations $\left(\mathrm{NH}_{3}-\mathrm{N} \mathrm{mg} / \mathrm{L}\right.$ seawater) were determined by the Nessler method using a HANNA C200 portable spectrophotometer (HANNA Instruments, Co., Italy) as described by Yigit et al. [32]. Prior to ammonia-N measurements, all experimental tanks were scrubbed and cleaned before start of experiment to minimize nitrification. Fish in CT were fed once a day in the morning and allowed to feed for 25 minutes, then uneaten feed were removed by siphoning. Water samples were taken from the tank at same time intervals as performed in RT and postprandial ammonia concentrations were analyzed. All measurements at each time intervals were conducted in triplicate.

Means are reported as \pm standard deviation (SD) of the mean. Statistical analyses were performed to examine the difference in ammonia- $\mathrm{N}$ excretion rates among the experimental groups. Ammonia-N excretion rates in experimental groups of fish exposed to transport and handling stress and those without stress were examined by the homoscedastic, two-tailed Student's $t$-Test, at a 5\% significance level [24].

\section{RESULTS}

No mortalities were recorded during transportation, indicating the lack of ammonia intoxication. At the end of transport, ammonia-N concentration in the transportation tank was 4 times higher than ammonia-N measured in sea water at the outlet facility (Table 2). After stocking the fish into the experimental recovery tank (RT), ammonia-N concentrations rose over time and reached a peak 10 hours later, and then declined to the initial values about $24 \mathrm{~h}$ after stocking (Fig. 1).

In fish under normal conditions and without stress (CT), postprandial trend of ammonia nitrogen excretion was similar to those under stress in terms of the rapid increase from 4-h onwards and return to initial values after 24 hours only with the difference that ammonia-N peak was observed 6 hours after feeding, while peak was reached $10 \mathrm{~h}$ after the initial point in fish exposed to stress (Fig. 2).

The peak values recorded in both goups of fish with -or without stress after $10 \mathrm{~h}$ and $6 \mathrm{~h}$, respectively, were about 3.8 times higher $(P<0.05)$ than the level recorded $4 \mathrm{~h}$ after the initial point. Even though a higher peak level was recorded for 


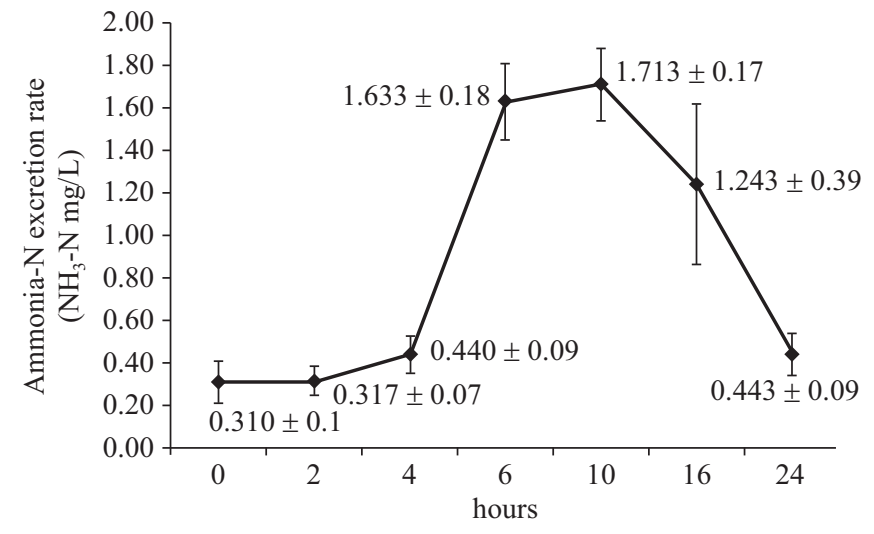

Fig. 1. Ammonia-N excretion rates over 24 hours in juvenile Sea Bass exposed to transport and handling stress $(n=388$ fish, fish weight (g) $=1.83 \pm 1.0$, mean \pm SD).

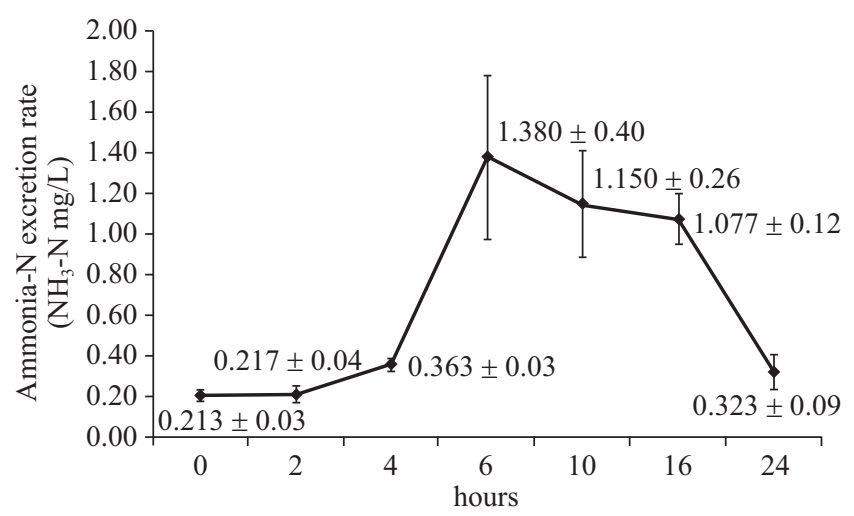

Fig. 2. Postprandial ammonia-N excretion for 24 hours in juvenile Sea bass without stress $(n=388$ fish, fish weight $(g)=1.83 \pm 1.0$ mean \pm SD).

fish under stress (10 $\mathrm{h}$ after the initial point), compared to that recorded for fish without stress ( $6 \mathrm{~h}$ after the initial point), the difference was not significant $(P>0.05)$ (Fig. 1 and Fig. 2).

Based on the duration of ammonia-N excretion recovery in fish, it is suggested that sea bass juveniles may completely recover from stress caused by transportation and handling, and return to normal feeding conditions in 24 hours after a 2-hour truck transport.

\section{DISCUSSION}

Evaluation of acute stress response and recovery time from transport stress is important issue for cost effective fish production, because the economic inputs primarily depend on the effective utilization of food [15]. Commercial aquaculture operations are willing to start feeding as soon as possible when fish arrive at the farm after transport. However, fish are being subjected to stress during transport that prevent appetite and obstructs effective feeding. Not only transport alone, but handling such as netting during transfer may cause additional stress to fish. Hence, when fish arrive at the farm they need recovery time from stressful conditions in order to optimize feed which directly affects feed utilization and feed conversion efficiency.

In the present study, transport and handling stress effects were the main stressors focused on, however, there are always additional stress effects in fish transportation, such as the noise of the vehicle, vibration caused by the road, etc. Besides, there were salinity differences between the seawater at the outlet site (the departure facility prior to transportation) and that of the experimental sea site. The difference in water salinity recorded in the transport tank and the experimental tanks is because the commercial fish farm uses lower layers of sea water in the Dardanelles (Strait of Canakkale), where the stream in deeper water layers presents the characteristics of the Aegean Sea. In the experimental facility however, water from the upper part of the stream, showing similar characteristics to the Black Sea conditions, was used. This might explain the difference in water salinity between the two sites, both located in the Dardanelles.

It is reported that the time course of the stress response is strongly influenced by the severity and duration of the stress itself [15]. Furthermore, different fish species might respond to various stressors in a different manner. Consequently this might explain the differences in stress response or the stress recovery time between different experiments conducted on acute handling or transport stresses. Wedemeyer [29] reported that young coho salmon refused feed and did not resume feeding for 4 to 7 days when fish were transferred by a hand net from one tank to another, in contrast, rainbow trout held under the same conditions returned to normal feeding behavior one day after transfer. Many researchers working on stressors and their effects on fish response mainly used hematological parameters as indicators for stress $[3,10,17,27,31]$. However, the methodology of this kind of approaches may influence the results, because blood sampling from alive fish is itself a source of stress [11, 12], and even careful removing fish from the tank during each sampling time can disturb the remaining fish in the tank and cause significant changes in their blood parameters [15]. Fecal glucocorticoid measurements were performed in parrotfish by using HPLC (highperformance liquid chromatography) [26]. Simontacchi et al. [22] demonstrated that cortisol were detectable in alternative matter such as mucus, gut content and muscle tissue and that it undergoes the same changes during the different stress times and conditions as the classical stress variables such as plasma cortisol, glucose and lactate in sea bass (D. labrax), hence, pointing out new possibilities for evaluating stress conditions in fishes where blood sampling is difficult. Interestingly, Ruane and Komen [18] measured cortisol levels in plasma and water ambience during a high density stocking experiment in carp, and reported that measuring cortisol levels in the water (a non-invasive stress assay) proved to be a useful indicator of stress levels in fish without inducing any disturbance. Furthermore, Xu et al. [30] reported that high levels of unionized ammonia levels in the water may affect behavioral responses 
of tilapia exposed to acute ammonia stress.

In the present study, ammonia nitrogen excretion rates were measured in the water as an indicator of acute stress caused by transport and handling procedures, and the recovery time from stress condition was evaluated. With the method applied here, neither fish were removed from the experimental tank at each sampling time, nor blood sample were taken from fish, only water samples were directly taken from the experimental tanks. Hence, any additional stress or disturbance effect on the experimental fish was avoided. Even though there are several studies elucidating the response of seabass $[3,6,7,22]$ or other fish species $[9,23]$ to stressors by using different indicators, less is known about the time needed for complete recovery of sea bass juveniles from stress and then return to normal condition or the renewal of appetite. Furthermore, the use of ammonia nitrogen excretion rates as an indicator of acute stress caused by transport and handling, demonstrates a practical and new approach for the evaluation of short time handling stress in fish.

As the sum of total $\mathrm{NH}_{3}-\mathrm{N}$ accumulation in the tanks was not important to our study, continuous water inflow and outflow $(1.7 \mathrm{~L} / \mathrm{min})$ throughout the study was maintained in order to avoid any additional water quality affected stress. With this methodology, it is obvious that the ammonia-N concentrations in water varied from true excretion rates, however, here it was important to see the trend of excretion (i.e., increase and decrease by time but not the accumulation). Otherwise, the results could have been influenced by the additional stress affect of the ammonia- $\mathrm{N}$ accumulation in the water.

It has been reported that fish exposed to increased ammonia concentrations may decrease growth rates, fecundity, disease resistance, and swimming performance, and it increases metabolic rate $[20,25]$. For example, rainbow trout exposed to increased ammonia concentrations $(50 \%$ of the $96-\mathrm{h}$ lethal concentration for rainbow trout, ca. $288 \pm 15 \mu \mathrm{mol} / \mathrm{l})$ showed a decrease in their critical swimming speed (from $2.23 \pm 0.15$ body length/s to $1.61 \pm 0.17$ body length/s), and an increase in the metabolic rate (from $3.04 \pm 0.86$ to $5.65 \pm 0.59 \mathrm{mmol}$ $\mathrm{O}_{2} / \mathrm{kg} / \mathrm{h}$ ) [21]. Elevated ammonia may cause increased gill ventilation, quick movements, loss of equilibrium, convulsions, lack of foraging, and mortality in fishes [13, 20].

An increase in metabolic rate is one of the responses of fish exposed to stress conditions. Considering that increased ammonia concentration increases metabolic rate in fish, a deduction can be drawn that fish exposed to stress conditions may increase ammonia excretion rate by means of elevated metabolism. Hence, it can be commented that ammonia excretion is a practical and useful indicator for evaluating the metabolic rate as well as stress conditions in fish. Based on these explanations, a relation between ammonia excretion rate and stress condition can be underlined in terms of increased ammonia excretion rates caused by occurance of stress conditions. According to the findings in the present study, fish exposed to transport and handling stress recoverd from stress after 24 hours, when ammonia excretion rates returned to the initial values.
The postprandial ammonia-N excretion trend in fish with no stress, had interesting indications for the return of appetite, hence the appropriate timing for the second feeding. Even though the return of ammonia excretion rate to initial values took about 24 hours, there was a peak 6 hours after feeding and ammonia excretion rates started a decrease, showing a basal stress level for fish and return of appetite. Hence, it might be suggested that the second meal can be delivered to sea bass juveniles 6 hours after the first feeding. Similar postprandial peak times of ammonia-N excretion rates were found in different fish species (i.e., 5-8 hours for Atlantic turbot-Scophthalmus maximus [1, 4, 5, 14], 3-6 hours for Japanese flounder-Paralichthys olivaceus [8]; 3-6 hours for Black Sea turbot- Scophthalmus maeoticus [32]. The time needed for gastric evacuation (required time for emptying the stomach) and so the return of appetite is reported as more than 24 hours in rainbow trout [19]. The reports of Ruohonen et al. [19] in rainbow trout also support and agree our findings in terms of the return of ammonia excretion rate to the initial levels after 24 hours post feeding in sea bass.

\section{CONCLUSION}

The findings in the present study demonstrate that measurement of ammonia-N excretion rates can be used as a practical indicator for evaluating the recovery time of fish from acute stress and that sea bass juveniles subjected to transport and handling stress may recover from the stress condition after 24 hours. Furthermore, the present study also demononstrates that the second meal in a day might be offered to the juveniles 6 hours after the delivery of the first meal for juvenile sea bass.

\section{ACKNOWLEDGMENTS}

The authors would like to thank Prof. Dr. Şükran CIRIK, Dean of the Faculty of Fisheries at Canakkale Onsekiz Mart University (COMU), for his valuable support throughout the study, which has been performed in partial fulfillment of requirements for the degree of Master of Science of the first author. Ida Gida AS (Marine Fish Farm), Canakkale-Turkey is gratefully acknowledged for their support of the experimental fish.

\section{REFERENCES}

1. Burel, C., Person-Le Ruyet, J., Gaumet, F., Le Roux, A., Severe, A., and Boeuf, G., "Effects of temperature on growth and metabolism in juvenile turbot," Journal of Fish Biology, Vol. 49, pp. 678-692 (1996).

2. Carneiro, P. C. F. and Urbinati, E. C., "Transport stress in matrinxã, Brycon cephalus (Teleostei: Characidae), at different densities," Aquaculture International, Vol. 10, pp. 221-229 (2002).

3. Caruso, G., Genovese, I., Maricchiolo, G., and Modica, A., "Haematological, biochemical and immunological parameters as stress indicators in Dicentrarchus labrax and Sparus aurata farmed in off-shore cages," Aquaculture International, Vol. 13, pp. 67-73 (2005).

4. Dosdat, A., Metailler, R., Tetu, N., Servais, F., Chartois, H., Huelvan, C., and Desbruyeres, E., "Nitrogenous excretion in juvenile turbot, Scophthal- 
mus maximus (L.), under controlled conditions," Aquaculture Research, Vol. 26, pp. 639-650 (1995).

5. Dosdat, A., Servais, F., Metailler, R., Huelvan, C., and Desbruyeres, E., "Comparison of nitrogenous losses in five teleost fish species," Aquaculture, Vol. 141, pp. 107-127 (1996).

6. Gornati, R., Papis, E., Rimoldi, S., Terova, G., Saroglia, M., and Bernardini, G., "Rearing density influences the expression of stress-related genes in sea bass (Dicentrarchus labrax, L.)," Gene, Vol. 341, pp. 111-118 (2004).

7. Guerriero, G., Di Finizio, A., and Ciarcia, G., "Stress-induced changes of plasma antioxidants in aquacultured sea bass, Dicentrarchus labrax," Comparative Biochemistry and Physiology Part A, Vol. 132, pp. 205-211 (2002).

8. Kikuchi, K., Sato, T., Iwata, N., Sakaguchi, I., and Deguchi, Y., "Effects of temperature on nitrogenous excretion of Japanese flounder," Fisheries Science, Vol. 61, pp. 604-607 (1995).

9. Kubilay, A. and Uluköy, G., "The effects of acute stress on Rainbow trout (Oncorhynchus mykiss)," Turkish Journal of Zoology, Vol. 26, pp. 249254 (2002).

10. Kuo, C. M. and Hsieh, S. L., "Comparisons of physiological and biochemical responses between milkfish (Chanos chanos) and grass carp (Ctenopharyngodon idella) to cold shock," Aquaculture, Vol. 251, pp. 525-536 (2006).

11. Laidley, C. W. and Leatherland, J. F., "Cohort sampling, anaesthesia and stocking density effects on plasma cortisol, thyroid hormone, metabolite and ion levels in rainbow trout, Salmo gairdneri Richardson," Journal of Fish Biology, Vol. 33, pp. 73-88 (1988).

12. Marino, G., Di Marco, P., Mandich, A., Finora, M. G., and Cataudella, S., "Changes in serum cortisol, metabolites, osmotic pressure and electrolytes in response to different blood sampling procedures in cultured sea bass (Dicentrarchus labrax L.)," Journal of Applied Ichthyology, Vol. 17 , pp. 115-120 (2001).

13. Meade, J. W., "Allowable ammonia for fish culture," The Progressive Fish Culturist, Vol. 47, pp. 135-145 (1985).

14. Pichavant, K., Person-Le Ruyet, J., Le Bayon, N., Sévère, A., Le Roux, A., Quéméner, L., Maxime, V., Nonnotte, G., and Boeuf, G., "Effects of hypoxia on growth and metabolism of juvenile turbot," Aquaculture, Vol. 188, pp. 103-114 (2000).

15. Pickering, A. D., Pottinger, T. G., and Christie, P., "Recovery of the brown trout, Salmo trutta L., from acute handling stress: a time-course study," Journal of Fish Biology, Vol. 20, pp. 229-244 (1982).

16. Portz, D. E., Woodley, C. M., and Cech, J. J. Jr., "Stress-associated impacts of short-term holding on fishes," Revision in Fish Biology and Fisheries, Vol. 16, pp. 125-170 (2006).

17. Robertson, L., Thomas, P., Arnold, C. R., and Trant, J. M., "Plasma cortisol and secondary stress responses of red drum to handling, transport, rearing density and a disease outbreak," The Progressive Fish Culturist, Vol. 49, pp. 1-12 (1987).

18. Ruane, N. M. and Komen, H., "Measuring cortisol in the water as an indicator of stress caused by increased loading density in common carp
(Cyprinus carpio)," Aquaculture, Vol. 218, pp. 685-693 (2003).

19. Ruohonen, K., Grove, D. J., and McIlroy, J. T., "The amount of food ingested in a single meal by rainbow trout offered chopped herring, dry and wet diets," Journal of Fish Biology, Vol. 51, pp. 93-105 (1997).

20. Russo, R. and Thurston, R., "Toxicity of ammonia, nitrite, and nitrate to fishes," In: Brune, D. E. and Tomasso, J. R. (Eds.), Aquaculture and Water Quality, World Aquaculture Society, Baton Rouge, LA, pp. 58-89 (1991).

21. Shingles, A., McKenzie, D. J., Taylor, E. W., Moretti, A., Butler, P. J., and Ceradini, S., "Effects of sub-lethal ammonia exposure on swimming performance in rainbow trout (Oncorhynchus mykiss)," Journal of Experimental Biology, Vol. 204, pp. 2691-2698 (2001).

22. Simontacchi, C., Poltronieri, C., Carraro, C., Bertotto, D., Xiccato, G., Trocino, A., and Radaelli, G., "Alternative stress indicators in sea bass Dicentrarchus labrax, L," Journal of Fish Biology, Vol. 72, pp. 747-752 (2008).

23. Skjervold, P. O., Fjæra, S. O., Østby, P. B., and Einen, O., "Live-chilling and crowding stress before slaughter of Atlantic salmon (Salmo salar)," Aquaculture, Vol. 192, pp. 265-280 (2001).

24. Student, "The probable error of a mean." Biometrika, Vol. 6, pp. 1-25 (1908).

25. Timmons, M. B., Ebeling, J. M., Wheaton, F. W., Summerfelt, S. T., and Vinci, B. J., Recirculating Aquaculture Systems, 2nd ed., Cayuga Aqua Ventures, Ithaca, NY, pp. 769 (2002).

26. Turner, J. W., Nemeth, R., and Rogers, C., "Measurement of faecal glucocorticoids in parrotfishes to assess stress," General and Comparative Endocrinology, Vol. 133, pp. 341-352 (2003).

27. Vazzana, M., Cammarata, M., Cooper, E. L., and Parrinello, N., "Confinement stress in sea bass (Dicentrarchus labrax) depresses peritoneal leukocyte cytotoxicity," Aquaculture, Vol. 210, pp. 231-243 (2002).

28. Walsh, P. J., Tucker, B. C., and Hopkins, E., "Effects of confinement crowding on ureogenesis in the gulf toadfish Opsanus beta," Journal of Experimental Biology, Vol. 191, pp. 195-206 (1994).

29. Wedemeyer, G., "Physiological response of juvenile coho salmon and rainbow trout to handling and crowding stress in intensive fish culture," Journal of the Fisheries Research Board of Canada, Vol. 33, pp. 26992702 (1976).

30. Xu, J. Y., Miao, X. W., Liu, Y., and Cui, S. R., "Behavioral response of tilapia (Oreochromis niloticus) to acute ammonia stress monitored by computer vision," Journal of Zhejiang University SCIENCE, Vol. 6B, pp. 812-816 (2005)

31. Yavuzcan-Yıldız, H. and Kırkağaç-Uzbilek, M., "The evaluation of secondary stress response of grass carp (Ctenopharyngodon idella, Val. 1844) after exposing to the saline water," Fish Physiology and Biochemistry, Vol. 25, pp. 287-290 (2001).

32. Yigit, M., Erdem, M., Aral, O., and Karaali, B., "Nitrogen excretion patterns and postprandial ammonia profiles in Black Sea turbot (Scophthalmus maeoticus) under controlled conditions," Israeli Journal of Aquaculture-Bamidgeh, Vol. 57, pp. 231-240 (2005). 